Katarzyna WARDIN

Polish Naval Academy

kwardin@wp.pl

\title{
ARMED CONFLICTS IN FRAGILE STATES AND THEIR INFLUENCE ON ILLEGAL MIGRATIONS AND REFUGEES \\ IN THE EUROPEAN UNION \\ IN THE $21^{\text {ST }}$ CENTURY
}

ABSTRACT The changes in the $21^{\text {st }}$ century have brought new threats and problems for the international community. The European Union, as one of the most important actors in the world, was forced to change its approach to a new situation, which is characterized by the presence of threats such as illegal migration, huge refugee influx and the existence of fragile states in its neighborhood. The main objective of this paper is to present the EU's engagement in stabilization of fragile states through civilian and military missions and operations to hold illegal migration. It answers the question whether the actions undertaken by the EU are powerful. The analysis of the operations and missions in chosen states (Somalia, Libya) shown that although the influx of migrants and refugees is lower, the changes and the influence of actions helping them to become stronger and more secure states are rather minor The conclusions comprise several thoughts which should be taken under consideration by the EU in the future in order to support European security and wealth.

Key words: armed conflicts, fragile states, migration, refugees, EU missions and operations 


\section{INTRODUCTION}

The world at the end of the $20^{\text {th }}$ century was supposed to be a safer and more prosperous place, but the terrorist attacks from the $11^{\text {th }}$ of September, 2001 showed that the world was definitely focused on different matters and it was not as secure as the community thought it had been. The beginning of the $21^{\text {st }}$ century made people realize that wealth is not the privilege of every country. Parts of the world are still in a very bad, fragile condition, and hundreds of millions of people suffer every day from hunger, diseases and lack of any help from their own governments. For this reason, the concept of security in the $21^{\text {st }}$ century, in the assessment of the author, has been considerably enlarged and next to the traditional threats which are still present, brand new threats of asymmetric, non-State nature have been emerging. It requires actions at many levels to fight them and the levels must not be restricted to the use of the armed forces only, but certainly because they endanger human lives of local populations and destabilize the regions they occur in, occasionally armed forces have to be the element of the help, given by the international community to weak and fragile countries. The objective of the article is to find an answer to a very important question whether the response of the European Union (EU) in neighboring African fragile states can help to stop the influx of illegal migration and refugees and give those states a chance to develop.

\section{FRAGILE STATES AND SECURITY}

Since the dawn of civilization man has had to deal with different threats that lurked both from other human beings and forces of nature, which persistently tormented humanity. Our ancestors, over time, built their collective sense of unity by organizing themselves in families and clans, stressing at the same time their different nature expressed by a different tradition, language or religious worship. By creating different tribes they represented local communities. Harsh natural conditions caused that in ancient times man had to defend himself against various dangers. It can be concluded that the defense against threats and, if necessary, the fight with them lies in the nature of man, who wants, at all costs, to ensure the best conditions for the survival and development of his family. Ensuring the most broadly understood security is the basic and most desired value common to all human beings.

As mentioned before, the terrorist attacks of $9 / 11$ made the whole world and the EU politicians reevaluate the perception of the international security environment and forced actions towards building a common approach to a new form of old threats, such as terrorism, local conflicts and wars, organized crime and state fragility.

One of the most important roles in changes which were taking place in the world at the turn of the century, was played by mega trends such as globalization, information revolution, demographic increase, threats to the environment, the processes of democratization of states, and, considered to be an insignificant one, the clash of different civilizations. The spontaneity of the processes and their dynamic range has resulted 
in changes to the security environment. It is difficult to indicate only one mega trend which could be considered the most important in this process. Probably it can be ventured to say that globalization is undoubtedly the source of emerging all previously unseen or new threats. It contributes in a large part to political destabilization in the world, its uneven development which leads to the exclusion of people, nationalities, countries or regions of the world, and that provokes all kinds of manifestations of fundamentalism. The lack of or very limited opportunities to earn decent money, poor prospects of good standard of living offered by the Western countries, are conducive to transnational, uncontrolled and pathological processes, such as international terrorism, organized crime, mass migration, human trafficking or maritime piracy. These usually result in weakening a state structure and its accountability for people.

The turn of the century has proved to be a period of changes in the approach to security as well, widening its concept with the Copenhagen school performance, which had a significant impact on the development of scholars. It was based on the concept of human security, formulated in the mid-90., which gave priority to the human dimension of security. ${ }^{1}$

It meant that bringing security down just to protection against external military aggression suppresses the aspirations of ordinary people seeking safety and security in everyday life. In the Human Development Report in 1994 the United Nations (UN) pointed out seven very important aspects of, the so called human security, among which the following can be found: economic security, personal security, perceived as the effectiveness of the security institutions in the country and political security, seen as manifested confidence to the government, its efficiency, the guarantee of fundamental freedoms and human rights, involvement in politics, and the perception of corruption problems. ${ }^{2}$ These ideas were clearly reflected in the approach to the security which requires a comprehensive approach, using a wide range of new possibilities to combat new threats in an integrated way. The threats to human security cannot be faced by only conventional mechanisms. They require a new consensus, which explicitly considers the whole network of linkages and interdependence between development, human rights and national security. That greatly extended the material scope of such aspects as the social, environmental or technological dimension as well as the demographic aspect of risks associated with migration.

The European Union, as one of important organizations in Europe and in the world, could not stay aside idly. The pressure of the changes taking place and the terrorist attacks in 2001, forced the EU to modify its course in terms of security. The EU security strategy, presented in 2003 listed some threats to international security, which had at that time and in 2018 still have a significant effect on the internal security conditions of the $\mathrm{EU}$ itself. The community faces new threats which are more diverse, but less visible and predictable:

A. Urbanek, "Bezpieczeństwo narodowe - podstawowe kategorie terminologiczne i ich klasyfikacja”, in A. Urbanek (ed.), Wybrane problemy bezpieczeństwa. Teoria. Strategia. System, Słupsk 2012, p. 15.

2 “Human Development Report 1994”, New York 1994, pp. 15, at <http://hdr.undp.org/sites/default/ files/reports/255/hdr_1994_en_complete_nostats.pdf >, 9 August 2018. 
- Terrorism;

- Proliferation of weapons of mass destruction;

- Regional conflicts;

- State failure;

- Organized crime. ${ }^{3}$

They are directly associated with the fact that the EU has its interests, in terms of security, outside its immediate neighborhood and cannot afford the exposure of these interests for financial losses and reduction in the standard of living in Europe. This is the main cause of the EU commitment to stabilization, peace building and long-term poverty reduction in its neighborhood, which is, as the EU evaluates, of fundamental importance in eliminating the enumerated threats. The political, diplomatic, humanitarian reaction to crises along with economic and trade cooperation development, as well as civil and military crisis management, are essential tools of response of the EU.

In reaction to global challenges in the security environment, the EU has clearly stated which of them need at the moment and potentially would require in the future strong community actions, by arranging the list of main threats. Next to the threats of greater or lesser intensity, a growing threat of a state failure has been listed.

This fact has not been of sufficient interest to the international community for many years. Different states were poor and in a bad condition, but nothing was really worrying. In case of the African continent, most problems were explained by its colonial past and difficulties with recovering their sovereignty, independence and implementing democratic roles. Although the conditions of living did not change in those countries, the so called "Old Continent" was safe. The situation in Africa and in the Middle East did not change and people were becoming more dissatisfied and frustrated. Governments kept losing more control of their territories and other important aspects of power. Economic problems started to appear and grow fast.

In many cases, economic failure has its background in political problems, wars and armed conflicts. Their presence contributes to the destruction of infrastructure, including social infrastructure, increased crime, they halt national and international investments, and prevent the conduct of regular business activities. Many countries and regions fall into the so-called vicious circle of conflicts, threats, and poverty. This state of affairs results in the creation of favorable conditions for the functioning for crime, including organized crime, the presence of terrorist organizations, maritime piracy, all forms of extremism and mass migration, which can have a devastating effect on already fragile and weak state structure.

State dysfunctionality is an alarming phenomenon, which is weakening the global law and also contributing to regional instability. The EU in its catalogue pays particular attention to this growing problem. Experts ${ }^{4}$, dealing with these issues try to not only diagnose

3 "European Security Strategy - A secure Europe in a better world", Council of the European Union, pp. 30-32, <http://www.consilium.europa.eu/media/30823/qc7809568enc.pdf>, 8 August 2018.

4 For instance, P. Collier - Director of the Center for the Study of African Economies, J. Putzel - Director of the Research Centre for countries in crisis, R.I. Rotberg - President Emeritus for Peace Foundation, D. Moyo - an expert of the World Bank. 
the factors that are responsible for the destruction of the State and cause of its weakness and fragility, but also to develop assistance programs, which are intended to result in direct commitment of the international community in the fight against this problem.

They stress that the lack of the state efficiency/stability is a process which starts with the weakening of the capacity to exercise effective power in a state, and consequently, leads to an advanced stage when such international entity is determined, as a fragile or failing. Regardless of the nomenclature used, they generate various forms of threats to security.

In the past decade global security deteriorated noticeably due to several important facts such as the growth of the number of terrorist and criminal groups and of course largely due to the expansion of the Islamic State (IS) into new territories. The number, complexity and lethality of all armed conflicts has increased, and they have been characterized by prolonged and shocking violence in large parts of the Middle East, Africa and the South Asia. These facts influence the world total number of forcibly displaced people, which reached over 65 million at the end of $2016^{5}$ and has soared in recent years. Countries like Afghanistan, Iraq, Israel and Palestine, The Central African Republic, the Democratic Republic of the Congo (DRC), Somalia or South Sudan have been torn by domestic conflicts and wars for many years or even decades. The best example would be Somalia, the country in the Horn of Africa, where the civil war was continued for over 25 years causing almost irreversible damages to the country and society. In other countries such as Tunisia, Libya, Syria, Egypt and Yemen the civil war took place in 2010-2011, as people's uprising and protests against worsening conditions of living and regime governments. Yet, the situation has not changed much in most of them, apart from the fact that the dictators have been overthrown. Most of them still suffer from lack of effective governance and many economic problems. The living conditions have not changed and people feel frustrated and deceived. All together there were seven active armed conflicts in the Middle East and North Africa in 2017. Only the complex war in Syria involving regional and international powers has led to the displacement of half the population - over 5.4 million refugees and over 6.1 million internally displaced persons - and 6.5 million people with acute food insecurity and a further 4 million at risk of the same ${ }^{6}$. The figures speak for themselves showing the tragedy of the people. Most of the migrants and refugees from that region have chosen the UE as their destination in the search for better life.

Geographically all of these countries, apart from Afghanistan, are located in the Middle East and Africa/North Africa, regions very important for the UE in terms of its economy and security. Most wars and armed conflicts, using the definition of the Department of Peace and Conflict Research, Uppsala University ${ }^{7}$ take place in the states

“SIPRI Yearbook 2018 Armament Disarmament and International Security. Summary”, p. 4, at <https://www.sipri.org/sites/default/files/2018-06/yb_18_summary_en_0.pdf>, 9August 2018.

6 Ibid., p. 5.

An armed conflict is a contested incompatibility that concerns government and/or territory where the use of armed force between two parties, of which at least one is the government of a state, results in at least 25 battle-related deaths in one calendar year. Conflicts causing at least 1,000 deaths in one 
listed on The Fragile States Index (Index), created annually by a Washington-based think-tank The Fund for Peace. ${ }^{8}$ What is even more alarming, almost all of them are placed at the top of the Index, as presented in the table 1.

Table 1. Top 10 countries from the Fragile States Index

\begin{tabular}{|c|c|c|}
\hline No. & Country name & Conflict yes/no \\
\hline 1. & South Sudan & Yes \\
\hline 2. & Somalia & Yes \\
\hline 3. & Central African Republic & Yes \\
\hline 4. & Yemen & Yes \\
\hline 5. & Syria & Yes \\
\hline 6. & Sudan & Yes \\
\hline 7. & Congo (DR) & Yes \\
\hline 8. & Chad & Yes \\
\hline 9. & Afghanistan & Yes \\
\hline 10. & Iraq & Yes \\
\hline
\end{tabular}

Source: Own source based on The Fragile States Index 2017

Countries such as Egypt or Libya are classified at the $36^{\text {th }}$ and $23^{\text {rd }}$ place respectively, which gives very clear information that they are not doing well and might have many difficulties with executing powers within the whole territory. It should be mentioned in this place that before the so called "Arab Spring" uprising both countries were classified on better positions. Egypt was at the $45^{\text {th }}$ place and Libya was the $111^{\text {th in }} 2010$, which means that in case of the latter, it was one of the worst changes that had a seriously detrimental effect on the security of the EU and the whole Europe in the years to come.

Not all of the conflicts or civil wars taking place in African countries and in the Middle East threaten the Europeans, unless they visit them as holiday destinations, which is quite common in case of Egypt, for example. All of these countries unfortunately suffer from the breakdown of the security structures, and they have become a kind of "gateways", used by different people to get to the EU as illegal migrants. The EU was confronted with this growing problem throughout 2015 and 2016 and in the opinion of many experts the problem will be constantly increasing if the UE does not take proper actions.

calendar year are considered wars. "Uppsala Conflict Data Program", <http://www.pcr.uu.se/digitalAssets/15/a_15880-f_UCDP_Battle-deaths__definitions_sources_methods.pdf $>, 9$ August 2018.

8 The Fragile States Index (FSI) is an annual ranking of 178 countries based on the different pressures they face that impact their levels of fragility. The Index is based on The Fund for Peace's proprietary Conflict Assessment System Tool (CAST) analytical approach, "Fragile States Index Annual Report 2017", Fund For Peace, <http://fundforpeace.org/fsi/2017/05/14/fragile-states-index-2017-annualreport/951171705-fragile-states-index-annual-report-2017/>, 8 August 2018. 


\section{THE EUROPEAN UNION OPERATIONS AND MISSIONS}

The European Union has undertaken many overseas operations, using civilian and military instruments in several countries, in three continents: Europe, Africa and Asia, as part of its Common Security and Defence Policy (CSDP). For the purpose of this paper the author focuses on actions connected to the African continent and chosen countries. The fact of enactment of CSDP gave the EU a possibility to lead autonomous operations outside its borders. It allowed the EU to organize missions based on civilian and military assets provided by member states. ${ }^{9}$ Each EU mission works in the framework of a comprehensive approach and in the agreement and coordination with the EU Delegations in the area and in the framework of the EU regional policies. They contribute to fight terrorism and support weak states to support their actions connected to security building.

Map number 1 shows the engagement of the EU in terms of civilian and military missions and operation in 2018. All together there were 16 missions and operations, 6 of them were military operations and 10 of them were civilian missions. It should also be noticed that out of 6 military operations, 5 are run in Africa and two, out of those 5, are maritime operations.

Most of civilian missions are located in Africa or in the Middle East. This indicates that the EU is particularly active in the regions neighboring Europe and of vital importance, in terms of economic businesses, international trade as well as safety and security of the continent. Unluckily, the most significant region for the EU is also the habitat for fragile states, with all the threats they pose to the nearest and further environment. The Middle East and African continent are critical not only for the EU member states but also for other European countries. Table 2 gives full names of the missions and operations run by the EU.

The author is going to analyze the operations which are, in her opinion, most influential in terms of the threats from fragile states and that is why she concentrates on Somalia and Libya and actions taken in these two countries. Somalia is at the top of the FSI from 2005 and Libya is the country with the worst outcome of the "Arab Spring", which became a paradise to human trafficking for the whole African continent.

Based on $5^{\text {th }}$ article of the $22^{\text {nd }}$ protocol added to the European Union Treaty and the Treaty on the Functioning of the European Union, Denmark does not participate in the elaboration and the implementation of decisions and actions of the Union which have deface implications. Therefore Denmark shall not participate in their adoption. Denmark will not prevent the other Member States from further developing their cooperation in this area. Denmark shall not be obliged to contribute to the financing of operational expenditure arising from such measures, nor to make military capabilities available to the Union, at <https://eur-lex.europa.eu/legal-content/EN/TXT/ ?uri=CELEX\%3A12012E\%2FPRO\%2F22>, 10 August 2018. 
Map 1. Civilian and military missions/operations of European Union in 2018

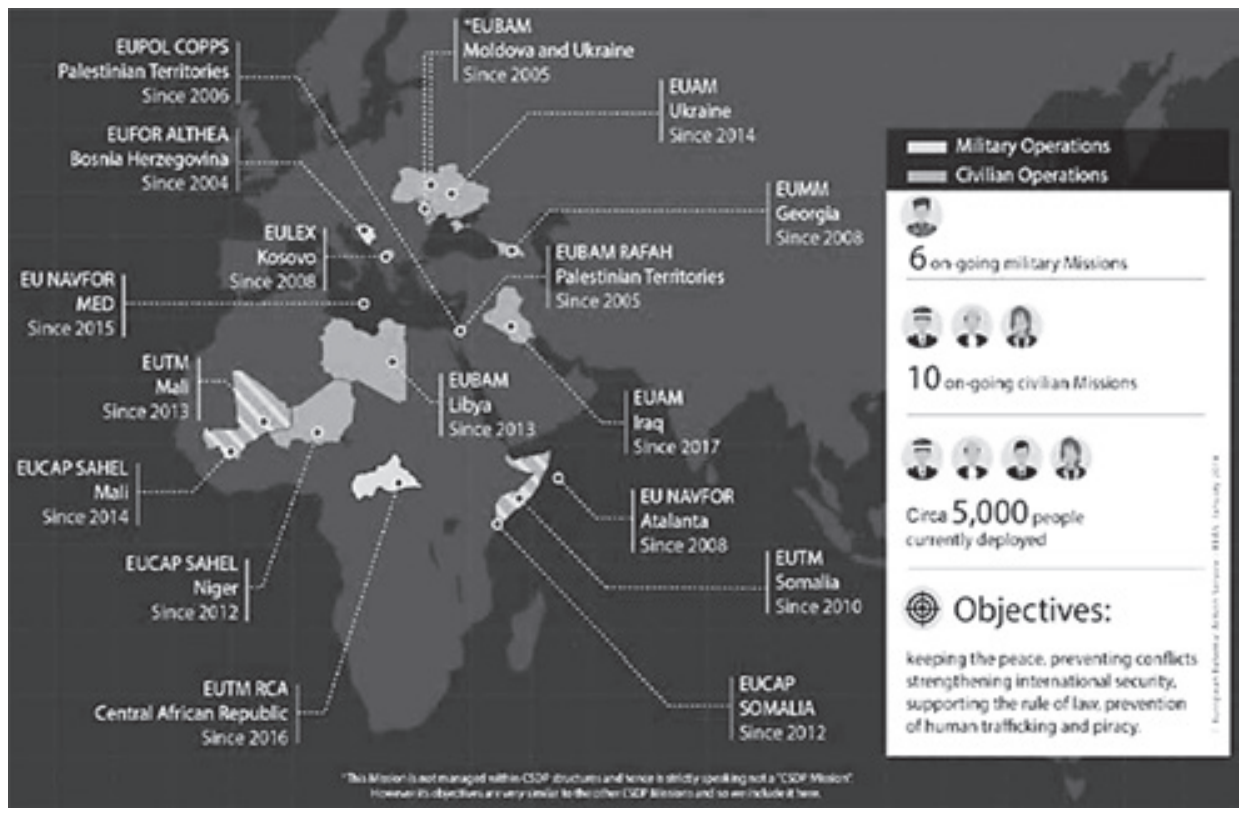

Source: Impetus. Magazine of the EU Military Staff, Spring/Summer 2018, issue 25, <https://eeas.europa. eu/sites/eeas/files/impetus_25_dp_final_eu_military_staff_magazine_impetus_25.pdf>, 10 August 2018.

Table 2. Civilian missions and military operations of the EU in 2018

\begin{tabular}{|c|c|c|c|}
\hline No. & Year & Operation/mission & $\begin{array}{l}\text { Continent/ } \\
\text { region }\end{array}$ \\
\hline \multicolumn{4}{|c|}{ Military operations } \\
\hline 1. & 2004 & $\begin{array}{l}\text { EUFOR Althea } \\
\text { European Union Force in Bosnia and Herzegovina }\end{array}$ & Europe \\
\hline 2. & 2008 & $\begin{array}{l}\text { EU NAVFOR Somalia } \\
\text { European Union Naval Force (Op Atalanta) Somalia }\end{array}$ & $\begin{array}{c}\text { Africa } \\
\text { Indian Ocean }\end{array}$ \\
\hline 3. & 2010 & $\begin{array}{l}\text { EUTM Somalia } \\
\text { European Union Training Mission Somalia }\end{array}$ & Africa \\
\hline 4. & 2012 & $\begin{array}{l}\text { EUCAP Somalia } \\
\text { European Union Regional Maritime Capacity Building for the } \\
\text { Horn of Africa and the Western Indian Ocean }\end{array}$ & $\begin{array}{c}\text { Africa } \\
\text { Indian Ocean }\end{array}$ \\
\hline 5. & 2015 & $\begin{array}{l}\text { EUNAVFOR MED Sophia } \\
\text { European Union Naval Force Mediterranean }\end{array}$ & $\begin{array}{l}\text { Mediterranean } \\
\quad \text { Sea }\end{array}$ \\
\hline 6. & 2016 & $\begin{array}{l}\text { EUTM RCA } \\
\text { European Union Training Mission in the Central African } \\
\text { Republic }\end{array}$ & Africa \\
\hline
\end{tabular}




\begin{tabular}{|c|c|c|c|}
\hline No. & Year & Operation/mission & $\begin{array}{l}\text { Continent/ } \\
\text { region }\end{array}$ \\
\hline \multicolumn{4}{|c|}{ Civilian Operations } \\
\hline 7. & 2005 & $\begin{array}{l}\text { EUBAM Rafah } \\
\text { European Union Border Assistance Mission to Rafah }\end{array}$ & Middle East \\
\hline 8. & 2005 & $\begin{array}{l}\text { EUBAM Moldova and Ukraine } \\
\text { European Union Border Assistance Mission to } \\
\text { Moldova and Ukraine }\end{array}$ & Europe \\
\hline 9. & 2006 & $\begin{array}{l}\text { EUPOL COPPS } \\
\text { European Union Police Mission for the Palestinian Territories }\end{array}$ & Middle East \\
\hline 10. & 2008 & $\begin{array}{l}\text { EULEX Kosovo } \\
\text { European Union Rule of Law Mission in Kosovo }\end{array}$ & Europe \\
\hline 11. & 2008 & $\begin{array}{l}\text { EUMM Georgia } \\
\text { European Union Monitoring Mission in Georgia }\end{array}$ & Europe/Asia \\
\hline 12. & 2012 & $\begin{array}{l}\text { EUCAP Sahel Niger } \\
\text { European Union Capacity Building Mission in Niger }\end{array}$ & Africa \\
\hline 13. & 2013 & $\begin{array}{l}\text { EUBAM Libya } \\
\text { European Union Integrated Border Assistance Mission in Libya }\end{array}$ & Africa \\
\hline 14. & 2013 & $\begin{array}{l}\text { EUTM Mali } \\
\text { European Union Training Mission in Mali }\end{array}$ & Africa \\
\hline 15. & 2014 & $\begin{array}{l}\text { EUAM Ukraine } \\
\text { European Union Advisory Mission Ukraine }\end{array}$ & Europe \\
\hline 16. & 2014 & $\begin{array}{l}\text { EUCAP Sahel Mali } \\
\text { European Union Capacity Building Mission in Mali }\end{array}$ & Africa \\
\hline
\end{tabular}

Source: Own source based on: "Military and civilian missions and operations", <https://eeas.europa.eu/ headquarters/headquarters-homepage_en/430/Military\%20and\%20civilian\%20missions\%20and\%20 operations>, 10 August 2018.

\section{THE OPERATIONS AND MISSIONS IN SOMALIA}

The situation in Somalia has been worsening from the beginning of the 21 st century, becoming very tense in 2008, when Somali maritime piracy took its toll and international community had to react to the threat. It was the first time in the history of the EU when it undertook military actions at sea to support its interests. UE NAVFOR ATALANTA Somalia started in December 2008 and has been continued ever since. ${ }^{10}$ The operation was the answer to hijacking ships carrying important goods to Europe e.g. oil and energy products, which were passing along Somali coast and in the Gulf of

10 K. Wardin, Wspótczesne piractwo morskie. Wyzwanie somalijskie oraz odpowiedź spoteczności międzynarodowej, Warszawa 2012, pp. 258-265. 
Aden. It turned out very soon that the problem was much deeper and had its roots on land, in the fact that Somalia, which was suffering from one of the longest and most cruel civil wars, became a fragile country without any power of its government over the territory or maritime assets. The operation was successful in reducing and almost eradicating piracy attacks in the region, but the situation had to be solved on land if the EU wanted to achieve a full success. For this reason, as shown in the table 2, in 2010 the EU started another military operation, this time it was a training mission in Somalia. Both of them focused on Somalia as a fragile state, with many problems connected to executing its powers.

Under the EU Council Joint Action 851, which is based on various UN resolutions, Operation ATALANTA is responsible for 4 tasks:

- Protects vessels of the World Food Programme (WFP), African Union Mission in Somalia (AMISOM) and other vulnerable shipping;

- Deters and disruptspiracy and armed robbery at sea;

- Monitors fishing activities off the coast of Somalia;

- Supports other EU missions and international organizations working to strengthen maritime security and capacity in the region ${ }^{11}$.

In July 2018 the Council of the EU extended the mandate of operation ATALANTA until December 2020. One of the main tasks is to help Somali government to control any illegal fishing activities off the coast of Somalia which had taken place in the past. The government has no real possibilities to control the territorial waters, contiguous waters (if appointed) or Economic Exclusive Zone - EEZ. Many years of the civil war resulted in the lack of reliable military forces in the country, not mentioning the Naval Forces, which basically do not exist. The Somali Navy was re-established in 2009 , but with a very tight budget - it might take many years to organize and equip a professional navy. Taking that under consideration, the EU launched in 2010 another military operation EUTM Somalia - European Union Training Mission Somalia in order to contribute to strengthening the Transitional Federal Government (TFG) and the institutions of Somalia.

In December 2016, the Council of European Union prolonged EUTM - Somalia until 31 December 2018 with a budget of close to $€ 27$ million for the period from 1 January 2017 to 31 December 2018.

The mission objectives concentrate on:

- Providing political and strategic level military advice and mentoring to Somali Authorities within the Defence institutions;

- Providing specific mentoring, advice, tailored training and capacity building in the training domain, in order to contribute to the development of the Somali National Armed Forces (SNAF) and be capable to fulfill their respective assignments in the Security Sector with a priority on delivery effective and sustainable security in Somalia.

- Playing essential role in the reform and enhancement of the capacity of Somalia's security institutions (focused on Ministry of Defence and General Staff), providing

11 EUNAVFOR Atalanta, at <http://eunavfor.eu/mission/>, 10 August 2018. 
military advice at the political and strategic levels to Somali authorities within the security institutions, and supporting the build-up of a sustainable Somali-owned military training system with a new training concept and training and advising in the Sector Headquarters;

- Training company level units (integrated and multi clan), carrying out courses to train future trainers (Train the Trainers Program) and conducting its advising and mentoring role in favor of Somali Ministry of Defense and Somali National Armed Forces (SNA) personnel. ${ }^{12}$

These activities are accomplished in close coordination with other international partners based in Somalia and they focus on stabilizing the country and executing the power of the Federal Government of Somalia. The absence of security institutions, military and police forces does not help the state to function and support the Somali people in everyday life. It is not the only reason for such poor conditions. It cannot be forgotten that $37,8 \%{ }^{13}$ of Somalis are illiterate (although there are no universal definitions and standards of literacy), and have very little opportunities of getting jobs or starting their own business. No social or health support makes the country one of the worst places to live in. It also pushed the people in 2008 to start to earn their living as maritime pirates and made many of them leave the country and become illegal migrants and refugees ${ }^{14}$. An estimated 280,000 Somali immigrants live in the European Union, Norway and Switzerland, largely due to a steady flow of asylum seekers. The EU, Norway and Switzerland are home to $14 \%$ of the world's Somali migrant population ${ }^{15}$. These are the problems that are not tackled by the missions directly but the outcomes have influence on the EU security and migration figures.

The third military operation started by the EU has been EUCAP Somalia (in the past EUCAP Nestor - European Union Regional Maritime Capacity Building for the Horn of Africa and the Western Indian Ocean). Following a strategic review of the mission, from the end of 2012, all activities focus exclusively on Somalia and they concentrate on and contribute to:

- the establishment and capacity building of maritime civilian law enforcement in Somalia, including Somaliland (part of former Republic of Somalia, not recognized as a separate state by International Community so far). ${ }^{16}$

The mandate of the mission is probably most important in establishing peaceful, stable, and democratic Somalia, which is crucial to make progress for both Somalis and the EU security and economy. The EU works to contribute to sustainable development

12 EUTM Somalia, at <https://www.eutm-somalia.eu/>, 10 August 2018.

13 Somalia Literacy, at <https://www.indexmundi.com/somalia/literacy.html>, 11 August 2018.

14 According to UNHCR in 2017 over 870,000 Somalis were registered as refugees in the Horn of Africa and Yemen, while an estimated 2.1 million men, women and children were displaced within the country itself, UNHCR-Somalia, at <http://www.unhcr.org/somalia.html>, 11 August 2018.

15 P. Connor, J.M. Krogstad, " 5 facts about the global Somali Diaspora", Factank. News in the numbers, 1 June 2016, at <http://www.pewresearch.org/fact-tank/2016/06/01/5-facts-about-the-global-somali-diaspora/>, 11 August 2018.

16 EUCAP Somalia, at <https://www.eucap-som.eu/about-us/>, 11 August 2018. 
and increasing stability and security in Somalia but also in the Horn of Africa and beyond. The situation is very complicated for several reasons such as clan rivalry, terrorist organization Al-Shabaab, very difficult climate conditions and droughts (the last disastrous one took place in 2017 leaving almost half of Somali population with food shortage). A stable and secure Somalia means increased security for the population and a chance for it to benefit from the peace dividends. It is vital for the country to start its new chapter in its history, and the mission, along with EU NAVFOR ATALANTA and EUTM Somalia, aims to help in achieving this goal. The EU must be aware of the fact that after 25 years of civil war and instability in the country, all political disputes and diplomatic activities over the nature of Somalia are essential but for ordinary people possibilities of getting work and every day security is more crucial. Unfortunately it is not an easy task to accomplish.

\section{THE OPERATIONS AND MISSIONS IN LIBYA}

The missions in Somalia are not the only ones dedicated to help fragile states and limit illegal migration and refugees. The most problems for the EU started with the "Arab Spring" and changes that took place in Libya, which became very quickly a dysfunctional and fragile state. The country has very rich resources of gas and oil. It was not a poor country in the past and its former leader Muammar Gaddafi (killed during the "Arab Spring") assured its citizens fairly prosperous life, cheap gasoline, free schools and health service, which was not common in other countries in Africa or in the Middle East. The strong rule of Gaddafi and lack of democracy as well as the uprisings in neighboring Tunisia took its toll. The country sank into a chaos and became an easy target for a terrorist organization called the Islamic State and also local clans' rivalry. The result of war lasting over 8 months was the transformation of power in Libya. The infrastructure of the country was destroyed and many cities burnt to the ground. The situation, in terms of the EU security and in Libya itself, was getting worse so the EU could not wait and it launched EUFOR Libya in April 2011.

After tedious negotiations, the EU managed to adopt a decision to establish the operation. The difficulties and the controversy which rose around the new crisis-response mission within the framework of the CSDP policy in Libya and various interests of the involved states influenced its very limited mandate. The adoption of a legal framework indicated readiness to respond but did not carry any opportunities to take action in practice. In November 2011, at the request of the operation commander, the command of the operation was closed. Several days later, the Council adopted a decision, under which the operation EUFOR Libya came to an end. Undoubtedly, the establishment of the operation in the formula of the legal and political conditions was a failure and embarrassment for the institutional apparatus of the EU. ${ }^{17}$

17 B. Przybylska-Maszner, “Operacja wojskowa EUFOR Libia”, in B. Przybylska-Maszner (ed.), Operacje wojskowe Unii Europejskiej w Afryce, Poznań 2014, p. 267. 
One of the consequences of the revolution was a significant wave of migration. Most of the migrants left Libya because of poverty and bad living conditions, however, some of them may be related to overthrowing and killing the leader and collapsing the old regime. Regardless of the reasons, they headed for Europe and the EU Member States, especially those closest to the Libyan borders.

The main result of the "Arab spring" and the civil war in Libya is a massive influx of migrants to Italy, where, more than 170 thousand migrants came to the South of the country in 2014. . Libya is not only very popular with the residents of Sudan, Niger, Chad, the Horn of Africa area, but also among the Syrians and the Palestinians, who try to leave the continent via Libya As mentioned, the UE has been struggling with a major migration crisis from the countries listed above since the beginning of the 2015. The influx destabilizes security and is the cause of disagreement and unanimous approach of Member States, in the relation to the arriving refugees and migrants. According to the Eurostat, the EU in 2015 received more than 1.3 million applications for asylum ${ }^{18}$ , which is more than twice as many as in the previous year. The source of this intensive migration to the EU has been and still is the instability of the area in the North African states, mainly in Libya. In addition, the ongoing from 2011 civil war in Syria also had a big impact on the current situation.

The Mediterranean basin is the main area of the influx of illegal migrants and refugees, where three main routes used for smuggling and human trafficking can be indicated. These are: the Western Mediterranean, the Central Mediterranean and the Eastern Mediterranean route. According to Frontex - the European Agency for border and Coast Guard, in the six months of 2018 the above-listed routes transferred to the EU, respectively, $14691,16067,24337$ people $^{19}$, which resulted in over 55 thousand refugees and migrants received in the first half of the year only. Those people do not travel on board of luxury boats or yachts but risk their lives traveling on old boats and dinghies. The situation was even deteriorating because of a high number of casualties at sea. According to the estimates of the International Organization for Migration (IOM) in 2015 about 3,771 immigrants drowned in the Mediterranean Sea. ${ }^{20}$ The EU could not stay indifferent to such a humanitarian crisis but it also had to defend its borders and internal security. A new mission EUBAM Libya (European Union Integrated Border Assistance Mission in Libya) started in May 2013

EUBAM Libya supports the Libyan authorities in developing border management and security at the country's land, sea and air borders. As a civilian crisis management mission with a capacity-building mandate, EUBAM assists Libyan authorities at a strategic and operational level. The work is carried out through advising, training and mentoring Libyan counterparts in strengthening the border services, in accordance

18 „Asylum statistics”, at < http://www.statewatch.org/news/2017/mar/eu-eurostat-2016-asylum-applications-statistics-explained-13-3-17.pdf>, 18 August 2018.

19 FRONTEX - European Border and Coast Guard Agency, Migratory map, at <https://frontex.europa.eu/along-eu-borders/migratory-map/>, 11 August 2018.

20 "IOM Counts 3,771 Migrant Fatalities in Mediterranean in 2015", IOM 2015, at <https://www.iom. int>, 20 August 2017. 
with international standards and best practices, and by advising the Libyan authorities on the development of a national Integrated Border Management (IBM) strategy. ${ }^{21 .}$ An unstable political and security situation in the country meant that the mission was enacted over only to a limited extent. In connection with the deteriorating security situation in the year 2014 in Tripoli, the decision was made in August about temporary evacuation of the mission to Tunis (Tunisia). From February 2015, the mission has deferred any of advice for Libyan entities. In connection with the mandate of the mission, expiring in May 2015, in April 2015 the Political and Security Committee (PSC) decided to extend it for further six months, until November 2015. The Council extended the mandate for another year in August 2016. It was extended again in 2017 till December 2018. The mission was for the most part unsuccessful and as mentioned, had to be withdrawn to Tunis due to a further deterioration of the security situation. ${ }^{22}$ The EU is fully aware of importance of security within Libyan borders, so the actions are undertaken to establish trustful security authorities. The changes announced by Libyan establishments which were to take place in 2018 (new constitution referendum, elections to parliament) provided some optimism as to the state condition. For this reason, the High Representative of the European Union for Foreign Affairs and Security Policy Federica Mogherini visited Tripoli in July 2018 on the occasion of inauguration of the EU offices. They will host the EU Border Assistance Mission in Libya, dedicated to managing particularly their land borders and the incoming diplomatic presence of the EU Delegation to Libya. ${ }^{23}$ The effects of the EU efforts to stabilize Libya will not be seen very soon and the community will have to be patient to see some improvements and the influx of migrants will become acceptable.

The EU is entangled in an unequal struggle with human traffickers at the Mediterranean Sea, and it rescues migrants pursuing three major operations. Operations "Poseidon" and "Triton" are carried out on behalf of Frontex, an agency within the EU structure. The third operation, undoubtedly of the most significant importance, is the military operation EU NAVFOR MED Sophia, implemented as part of the CSDP against smugglers. The article focuses on Sophia, because its mandate has a great impact on the situation in Libya as a fragile state.

The decision on the establishment of the military naval operation EU NAVFOR MED Sophia, carrying out its activities in the central part of the Mediterranean, was taken by the Council during its meeting in May 2015. At the beginning of its active phase in June, 2015 the mandate of operation covered the period of 12 months.

The operation is designed around 4 phases:

- the first consists of the deployment of forces to build a comprehensive understanding of smuggling activity and methods, and this phase is now completed;

21 EUBAM Libya, at <https://eeas.europa.eu/csdp-missions-operations/eubam-libya/3859/about-euborder-assistance-mission-libya-eubam_en>, 19 August 2018.

22 G.H. Christensen, "The European Union Border Assistance Mission in Libya - successes, shortcomings and lessons identified", Royal Danish Defence College Brief, Copenhagen 2018, p. 3.

23 EUBAM Libya. 
- phase two foresees the boarding, search, seizure and diversion of smugglers' vessels on the high seas under the conditions provided for by applicable international law. This activity will be extended into territorial waters upon the release of any applicable United Nation Security Council Resolution (UNSCR) and the concerned coastal State consent;

- the third phase expands this activity further; up to and including taking operational measures against vessels and related assets suspected of being used for human smuggling or trafficking inside the coastal states territory. Once again, this is subject to the necessary legal framework established by UNSCR and following coastal state consent;

- finally, the fourth and last phase will consist of withdrawal of forces and completion of the operation. ${ }^{24}$

In June 2016 the Council extended the operation to July 2017 and added two reinforcing goals:

- training of the Libyan coastguards and navy;

- contributing to the implementation of the UN arms embargo on the high seas off the coast of Libya ${ }^{25}$

The Council again extended the mandate of the operation in July 2017 until the end of December 2018 and expanded the mandate of the operations with the following tasks:

- creation of a mechanism for monitoring Libyan officers trained Coast Guard, designed to provide long-term effectiveness of training;

- carrying out new activities for the observation and collection of information about the illegal export of Libyan oil in accordance with UN SC Resolutions 2146, 2014 and 2362, 2017;

- increasing the possibility of exchanges of information with the law enforcement authorities of the Member States, Frontex and Europol on trafficking in human beings. ${ }^{26}$

The previous success of the operation is mainly connected with saving human life at sea and constricting illegal migration, which was down by $9 \%$ in 2016, in comparison to 2015. This can be considered as an achievement for the EU migrants' problem and security, but it is very difficult to state unanimously whether the operation contributes to the condition of the Libyan state. Probably the most important would be further tasks connected with training the Libyan Navy personnel and Coast Guards. It cannot be forgotten that, because of the fact that the state is fragile, the level of corruption is very high and training uniform personnel does not mean that they would become honest civil servants resistant to bribery. The tribal structure of the Libyan society makes the situation even more complicated and exposes

24 EUNAVFOR Sophia, at <https://www.operationsophia.eu/about-us/>, 18 August 2018.

25 Ibid.

26 EUNAVFOR Med Sophia: mandat przedłużony do 31 grudnia 2018 r., UE 2017, at <www.euractiv. pl>, 3 September 2017 . 
the mission to complex difficulties. In such a society, the lack of loyalty to a tribe or clan the person belongs to is considered as a betrayal and punished with death. The choices that young, trained personnel will have to make will not be easy for them, but, on the other hand, the future of the state will depend on their reliability. It is relatively easy to organize training for the personnel at a certain time but it is very difficult to change somebody's mentality over a period of several months. This would be the most challenging task of the mission, and, looking back at previous operations, the author doubts if the EU is aware of this task and, moreover, whether it is prepared to take the right actions.

Organized crime groups and various terrorist organizations will try hard to maintain their control over the situation and the country in order to continue illegal businesses and to earn money. In terms of human trafficking, as long as there are people ready to risk their lives and take that dangerous maritime route to Europe, there will always be somebody willing to help them and make business out of those dealings.

\section{CONCLUSIONS}

The majority of states on the African continent received their independence in the 1960s, which obviously works against them in terms of possible advances and smooth, fast changes. Examining civilian missions and military operations organized by the European Union in Africa, there are some thoughts that come forward and may be considered as conclusions to this article.

- The member states do not have a coherent approach to fragile states because they have different businesses in Africa, in general (EUFOR Libya). Some of them are interested in getting involved, some of them, having no particular concerns, prefer to stay away from fragile states and their problems.

- If the EU decides to take action it is usually only because of the direct threats to the EU businesses. Missions or operations very often do not take into consideration the history of the continent, specificity of a clan/tribe society structure, the religious background and a very low education level, which are not indifferent in the success of any mission or operation.

- The EU missions and operations and their mandates are usually very ambitious and assume many tasks, which are rather difficult to achieve within several months. They are probably unachievable in two, three or even four years of the mission. Some of them become permanent missions in order to ensure achieved results (EUNAVFOR Atalanta). Even if they last longer, eventually, the personnel is limited to 10-30 people who have little influence on the country's situation. Sometimes the mission must be withdrawn for a certain period of time because of security problems (EUBAM Libya).

- The missions and operations are expensive, especially the military ones, ${ }^{27}$ and they

27 For example the EUNAVFOR Atalanta operation cost the EU 8,4 mln $€$ in 2010 but only to covers 
require financial engagement in setting them up, equipping and keeping functioning along with the funds for implementation of the missions' mandates. Taking into consideration that they are located in fragile states, the budget of the mission should be really plentiful. That fact always raises doubts whether the money is spent sensibly. The present mechanism of mission set-up depends really on the willingness of the participating states only, in this situation not every Member State of the EU is involved in shaping CSDP and reacting to the threat of illegal migration and refugees, but most of them suffer from this problem.

- Poor results of missions and operations are also connected with the fact that some of European states and personnel of the missions are treated cagily by the locals or in some cases are not welcome in Africa at all, because of the past colonial history or religion. That also has an effect on the success of the EU involvement.

- Although the EU declares that it learns its lesson from the previous missions or operations, the overall impression might be different. It can be seen most vividly in the permanent assumption that the EU's financial help depends on the level of democratic reforms introduced in particular states, which in case of the African continent, its history, tradition, religion, is more than difficult and should not be stressed to such an extent. A very high level of literacy is not helping in achieving good results of missions and operations, either. Even though the $\mathrm{EU}$ is aware of difficulties in introducing democratic rules in African states, it is the key element of any help offered.

Certainly, the actions taken by the EU are a response to a migrant/refugee crisis in Africa and the Middle East, which has been unprecedented so far. In these circumstances, the measures taken are rather a forced reaction to the situation, which turns out to be less effective than expected. In terms of the support effectiveness in African fragile states, the engagement is insufficient to have truly positive effects, in the author's opinion. ${ }^{28}$ The EU should respond to mistakes and shortcomings on a regular basis so that it can make its actions more productive and the money could be spent in a wiser way. The mandates of the missions and operations should be more flexible and adjustable to a current situation in a particular state, where a mission is organized.

Answering the question whether the response of the European Union in the neighboring African fragile states can help to stop the influx of illegal migration and refugees, the author is quite skeptical. The missions and operations are rather a reaction to the threats and they limit these threats somehow, but they are not much of help in terms of

the financing of common costs, such as costs for the Operational Headquarters and the Force Headquarters, as well as medical services and transport. Costs of supplying military assets and personnel are shared by the contributing states according to their involvement in the operation, with each state bearing the cost of the resources it deploys, K. Wardin, Wspótczesne piractwo..., pp. 262-263.

28 During 22 years of civil war in Somalia all international help fluctuated around 23 billion of USD. According to the author's research, the elimination of Somali piracy threats and costs paid by international community hit approximately the same amount of USD only in two years time (2010,2011). K. Wardin, Model reagowania na zagrożenia piractwem morskim, Warszawa 2014, p. 297. 
changing the conditions which lie behind the problems. EUNAVFOR ATALANTA may be a good case in point here. It has limited piracy attacks in the region but has not made along with other missions (EUTM Somalia, EUCAP Somalia) any significant change on land and inside the state. Somalia has taken the first or second place on the FSI ever since its first edition in 2005.

If the EU's help is to be more successful in terms of time and effectiveness, the Member States should change their approach to the mechanism of missions and should have the European Union Army at their disposal. The idea is not new but because of Great Britain's leaving the EU and illegal migration problems, it can be heard more often that the EU should have its own army by the end of 2025. The President of the European Commission Jean-Claude Juncker, delivering an annual State of the Union address to the European Parliament said in September 2017: The defense sphere requires more efforts. Establishment of the European Defense Fund is included on our agenda, as well as the Permanent Structured Cooperation (PESCO). By 2025, we need a functioning European defense union. We need it, and NATO would like us to have it ${ }^{29}$. This may simplify and speed up the launching of missions and operations as a reaction to different crises. A fast reaction in a weakening state can help to stabilize the situation and prevent human disasters, which usually accompany such problems. It would also be more just, because all members should participate in such missions with no exceptions but also could share different experiences and attitudes which would bring better effects. The commitment of the EU cannot be limited to a military reaction only and there should be a great shift of the EU's involvement on civilian missions with higher budgets and long-term engagement. Reacting to present and future threats means helping fragile states in Africa to achieve better conditions of education, healthcare, social care and internal security, which can really change living conditions in those states. It should be a commitment considered as a long-term investment for the future generations. It is necessary to undertake such actions in the near future if the European Union wants to stay a secure, safe and wealthy continent for its citizens.

\section{BIBLIOGRAPHY:}

"Brussels should establish European Defence Union by 2015 - Juncker", Sputnik News, 13 September 2017, at <https://sputniknews.com/military/201709131057353053-european-defense-union/>, 21 August 2018.

Connor P., Krogstad J.M., "5 facts about the global Somali Diaspora", Factank. News in the numbers, 1 June 2016, at <http://www.pewresearch.org/fact-tank/2016/06/01/5-facts-aboutthe-global-somali-diaspora/>, 11 August 2018.

29 Brussels should establish European Defence Union by 2015 - Juncker, "Sputnik News", 13 September 2017, at <https://sputniknews.com/military/201709131057353053-european-defense-union/>, 21 August 2018. 
EUBAM Libya, at <https://eeas.europa.eu/csdp-missions-operations/eubam-libya/3859/ about-eu-border-assistance-mission-libya-eubam_en>, 19 August 2018.

EUCAP Somalia, at <https://www.eucap-som.eu/about-us/>, 11 August 2018.

EUNAVFOR Atalanta, at <http://eunavfor.eu/mission/>, 10 August 2018.

EUNAVFOR Med Sophia: mandat przedłużony do 31 grudnia 2018 r., UE 2017, at <www. euractiv.pl>, 3 September 2017.

EUNAVFOR Sophia, at <https://www.operationsophia.eu/about-us/>, 18 August 2018.

"European Security Strategy - A secure Europe in a better world", Council of the European Union, at <http://www.consilium.europa.eu/media/30823/qc7809568enc.pdf>, 8 August 2018.

EUTM Somalia, at <https://www.eutm-somalia.eu/>, 10 August 2018.

"Fragile States Index Annual Report 2017", Fund For Peace, at <http://fundforpeace.org/ fsi/2017/05/14/fragile-states-index-2017-annual-report/951171705-fragile-statesindex-annual-report-2017/>, 8 August 2018.

FRONTEX - European Border and Coast Guard Agency, Migratory map, at <https://frontex. europa.eu/along-eu-borders/migratory-map/>, 11 August 2018.

Højstrup Christensen G., "The European Union Border Assistance Mission in Libya - successes, shortcomings and lessons identified”, Copenhagen 2018.

“Human Development Report 1994”, New York 1994, at <http://hdr.undp.org/sites/default/ files/reports/255/hdr_1994_en_complete_nostats.pdf>, 9 August 2018.

"IOM Counts 3,771 Migrant Fatalities in Mediterranean in 2015", IOM (2015), <https:// www.iom.int>, 20 August 2017.

"Military and civilian missions and operations", at <https://eeas.europa.eu/headquarters/headquarters-homepage_en/430/Military\%20and\%20civilian\%20missions\%20and\%20operations>, 10 August 2018.

Protocol added to the European Union Treaty and the Treaty on the Functioning of the European Union, at <https://eur-lex.europa.eu/legal-content/EN/TXT/?uri=CELEX\%3A12 012E\%2FPRO\%2F22>, 10 August 2018.

Przybylska-Maszner B., "Operacja wojskowa EUFOR Libia”, in B. Przybylska-Maszner (ed.) Operacje wojskowe Unii Europejskiej w Afryce, Poznań 2014.

SIPRI Yearbook 2018 Armament Disarmament and International Security. Summary", at $<$ https://www.sipri.org/sites/default/files/2018-06/yb_18_summary_en_0.pdf>, 9 August 2018.

Somalia Literacy, at <https://www.indexmundi.com/somalia/literacy.html>, 11 August 2018.

UNHCR in Somalia, at <http://www.unhcr.org/somalia.html>, 11 August 2018.

"Uppsala Conflict Data Program", at <http://www.pcr.uu.se/digitalAssets/15/a_15880-f_ UCDP_Battle-deaths_-_definitions_sources_methods.pdf>, 9 August 2018.

Urbanek A. (ed.), Wybrane problemy bezpieczeństwa. Teoria. Strategia. System, Słupsk 2012. Wardin K., Model reagowania na zagrożenia piractwem morskim, Warszawa 2014.

Wardin K., Wspótczesne piractwo morskie. Wyzwanie somalijskie oraz odpowiedź spoteczności międzynarodowej, Warszawa 2012. 
Prof. Katarzyna WARDIN, Ph.D. - works as an associate professor at the Polish Naval Academy in Gdynia, Command and Naval Operations Faculty. She graduated from the University of Gdańsk in political science and public policy, in 2007, she received the $\mathrm{PhD}$ title in the specialty maritime state security. She obtained the title of D.Sc. in the field of social sciences, specialty security at the Polish Naval Academy in Gdynia in 2014. She is the author of numerous scientific papers in national and foreign magazines on maritime transport security and its contemporary threats, with particular emphasis on maritime piracy and terrorism, illegal migration and refugees. She takes active participation in national and international conferences presenting her research findings. In addition, Ms Wardin conducts research in the area of international political relations and international security, security of the EU to as well as the threats caused by weak and fragile states with a special focus on Somalia. 